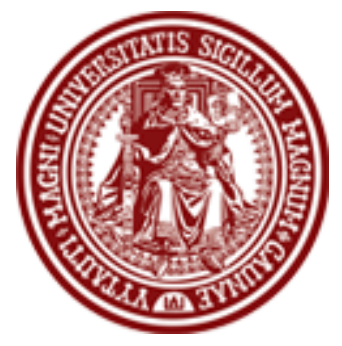

BALTIC JOURNAL OF LAW \& POLITICS

VOLUME 5, NUMBER 1 (2012)

ISSN 2029-0454

http://www.versita.com/bjlp

Cit.: Baltic Journal of Law \& Politics 5:1 (2012): 1-19

DOI: $10.2478 / \mathrm{v} 10076-012-0001-3$

\title{
ON INTERNATIONAL TRANSACTION LAW: CURRENT TRENDS AND CHALLENGES FROM A LATIN AMERICA PERSPECTIVE
}

\author{
José Gustavo Prieto Munoz \\ Professor \\ Simon Bolivar Andean Community University, UASB (Ecuador) \\ Del Pacifico University, Faculty of Law (Ecuador) \\ Contact information \\ Address: Robles 653 y Amazonas, Edif. Proinco, of.709, Quito, Pichincha, Ecuador \\ Phone: +5932552658 \\ E-mail address: gprieto@inteclawgpm.com
}

Received: January 10, 2012; reviews: 2; accepted: May 11, 2012.

\begin{abstract}
During the last decade of the twentieth century, international transactions that involve the movement of capital throughout the world achieved unprecedented frequency of usage. The consequences of this were felt at international and national levels. On the international level there was a creation of a great amount of Bilateral Investment treaties (BIT) between states that regulate and provide substantive norms as well as dispute resolution mechanism that bring out enormous numbers of unarticulated arbitral decisions. On the national level, many states modified national legislation to attract foreign investment. These modifications created a complex system that regulates international transactions. However, during the last years there have been two trends in investment among developing countries: one that supports the current legal framework, and another that seeks to find a new ordering of the field. The present article will explore these trends from the Latin America experience by analyzing how this law evolved in the region by studying the structure of the investment regulation of the main integration processes, and finally, by formulating a new understanding of the way that this type of law should be interpreted while dealing with sensible issues.
\end{abstract}




\section{KEYWORDS}

International Economic Law, International Investment Law, Latin America, MERCOSUR, Andean Community 


\section{INTRODUCTION}

During the last decade of the twentieth century, international transactions that involve the movement of capital throughout the world achieved record numbers. According to UNCTAD, in that decade foreign investment flows quadrupled in what was part of a phenomena call globalization. This growth began to develop independent branches of international economic law that specialized in regulating these types of transactions. This law is composed of a series of layers or strata, formed by "general international law, general standards of international economic law, and distinct rules peculiar to its domain." ${ }^{1}$

As a consequence of these transactions, there has been an interesting development at both the international and national levels. On the international level, there was a creation of regional agreements, and many Bilateral Investment treaties (BIT), that regulate and provide substantive norms as well as dispute resolution mechanisms that bring out enormous amounts of unarticulated arbitral decisions. At the national level, many states have modified national legislation to attract or to control foreign investment. These modifications have created a complex system that regulates international transactions. However, during the last few years there have been two investment law trends among developing nations: one that supports the current complex legal framework, and another that seeks to develop a new one.

The present article will seek to provide an analysis on these trends from the Latin America point of view. The first part of the article deals with globalization concepts; the second part will examine the evolution of the regulation of transactions in the region, including an analysis of the main integration processes, the MERCOSUR and the Andean Community; the third part will discuss where these trends of regulation are going; finally, the last part will explore a new understanding of the way that investment regulation should be interpreted while dealing with sensitive areas of any state's policy.

\footnotetext{
${ }^{1}$ Rudolf Dolzer and Chrisoph Schreurer, Principles of International Investment Law (Oxford University Press, 2008), p. 3.
} 


\section{GLOBALIZATION AND INTERNATIONAL TRANSACTION LAW}

Many scholars have written about globalization, so in order to develop the present article, it is important just to emphasize the most important points that have affected the way that law is conceived in the area of analysis.

First, globalization is a concept that should always be understood in a plural, and not in a singular way. This means that there is not a single process but many globalized ones, "each of them has its own logic and rhythm." ${ }^{2}$ Therefore, we can talk about cultural, financial, economic, and legal globalizations (among others) that have been evident during the past years. For that reason, it would be a mistake to consider all these processes to be autonomous to one another, because that can lead to a misinterpretation of the changes that the law has overcome during the last decade.

In addition, it is also important to establish that these different processes have a characteristic in common, which is that there is an unequal balance of forces among the actors leading globalization processes. For example, in cultural globalization it is easy to see that many of the features of the cultures of the developing nations, such as food and lifestyle habits, are more widespread beyond their own borders than those from economically weaker countries. In the same way, another example is that, even though the different globalization processes have included many actors around the globe, the language that is present in most international transactions is English ${ }^{3}$.

The legal process of globalization, however, has a unique feature that makes it different from the other ones: it needs more time to establish itself and develop. For instance, only when crime started to globalize was there also the need to find legal solutions; in the same way, when individuals and corporations started to dramatically increase the number of transactions abroad, the need emerged to regulate these transactions; but, the ability to adapt to change is very limited in this area. As Friedman stated: "The legal world may be, in some ways, one of the more primitive sectors of modern life - less globalised than many other aspects of that life." ${ }^{4}$ This idea can be explained by the fact that wisdom or knowledge in the legal field tends to be static, probably because a great number of scholars or lawyers are focused on the study of the domestic legal system rather than international and comparative law.

\footnotetext{
2 M. Carbonell, Globalización y Derecho: Algunas Coordenadas para el Debate (Quito: Ministerio de Justicia Ecuador, 2009), p. 20.

${ }^{3}$ This is also applies to academic documents in the field of law, for instance this same article is written in English language.

4 L. M. Friedman, "One World: Notes on the Emerging Legal Order": 25; in: Transnational Legal Processes (Butterworths LexisNexis, 2002), p. 25.
} 
Finally, this process of change has modified the way that legal wisdom is structured. In general, it can be said that lawyers and legal scholars have the tendency to label transactions in a different way, such as: private and public; or, international and national. In that sense, other processes of globalization, such as the economic one, have generated a crossroads that in a way changes the gravity of legal wisdom. For example, like Orrego explains, ${ }^{5}$ when transactions were mostly national, international law applied in a subsidiary way. But now that a great majority of transactions involve parties from different states, national law plays a secondary role.

For that reason, the legal framework that regulates international transaction is a unique one because it involves features that come from different types of law, both private and public, national and international. Also, this legal framework can be approached from different perspectives, and legal fields; in that sense, the evolution of it can also be analyzed from different geographic regions.

\section{THE EVOLUTION OF INTERNATIONAL LAW REGULATION OF INVESTMENT IN LATIN AMERICA}

The evolution of the legal framework that regulates international transactions can be traced through three periods: the first is a colonial period in which individuals from the states that export capital did not need special protection because the colonies were under the imperial laws and regulations; ${ }^{6}$ a second is a period when states started gaining independence and therefore felt the need to recover strategic sectors by nationalizing property, which creates the debate of what was the level of treatment required by international law; ${ }^{7}$ and, finally, a modern period that tried to establish a legal frame using the conventional source(s) of international law.

This evolution can be seen in the region because most countries were Spanish colonies until the nineteenth century, except for Brazil, which was a Portuguese colony. However, those territories started to gain their independence and even tried to create a federal State ${ }^{8}$ as in the case of the Andean states that created the Gran Colombia. ${ }^{9}$ This State only lasted ten years, and its members existed as new states.

\footnotetext{
5 Francisco Orrego Vicuña, De los Contratos y Tratados en el Mercado Mundial en Inversiones Extranjeras (Buenos Aires, 2005), p. 25.

${ }^{6}$ M. Sornarajah, The International Law On Foreign Investment (Cambridge: Cambridge University Press, 2004), p. 23.

7 Surya P. Subedi, International Investment Law Reconciling Policy and Principle (Portland: Hart Publishing, 2008), p. 7.

8 Oscar Efrén Reyes, Breve Historia del Ecuador (Quito: Gráficos Nacionales, 1949), p. 354.

9 Gran Colombia was a federal State created in the territories of Ecuador, Colombia, Venezuela and Panama. This State only lasted 10 years.
} 
In contrast, the Portuguese colonies were able to remain together and created a federal State at the end of the nineteenth century.

In this period, there were conflicts between national exporting capital states and these newborn ones. These conflicts can be synthesized in the encounter of two positions, the one of the host State that tried to nationalize transactions, therefore applying local law and submitting the transactions to the local courts; and other one that sought to internationalize transactions - a position adopted for the investor in order to apply laws different from those of the host State.

Among the conflicts, one of the most famous ones of this period was the Mackintosh incident. This case began in 1822 when a British merchant sold weapons and supplies to Gran Colombia, and received a subsequent refusal to pay. This resulted in a British government order to send a squadron of five ships to Cartagen ${ }^{10}$ and in 1857 issued an ultimatum "threatening to bomb the city if they did not pay the debt." ${ }^{11}$ As an anecdotal end, the crew of British ships suffered a tropical disease that forced them to land and receive help from the local people. ${ }^{12}$ However, the ending of this incident represents how the powerful state inflicted pressure on the weaker one in order to achieve its goals because there were no other means than power to solve a dispute.

This type of pressure on the part of the exporting capital states generated a doctrine that for many years was the basis of international relationships of the Latin American states. This was known as the Calvo Doctrine, which took the name of its creator, Carlos Calvo, a jurist from Argentina. This Doctrine can be summarized in two elements: one is related with the international responsibility of host states and the other one is related to jurisdiction. About the first element, the doctrine states that "the responsibility of governments toward foreigners cannot be greater than that which these Governments have towards their own citizens. "13 The second element of the doctrine is the requirement for aliens to submit disputes arising in a country to its local courts. ${ }^{14}$ Consequently, the legal basis of this doctrine is the equality ${ }^{15}$ between national and aliens.

In the third period, Latin American states started to leave behind the Calvo doctrine, when they started to sign Bilateral Investment Treaties (BIT), which contain standards of treatment such as the fair and equitable standard, among

\footnotetext{
10 Today it is a city of Colombia

11 Nigel Blackaby, "El arbitraje según los tratados de inversión y los capítulos de inversión en los tratados de libre comercio": 285; in: El Contrato de Arbitraje (Bogotá: Legis Editores, 2005).

12 The bombing never happened because the officer in charge of the operation requested his Government to postpone the order of bombing.

13 Adriana Sánchez Mussi, "International Minimum Standard of Treatment," Worldpress Web Site, 2008:

4 // http://asadip.files.wordpress.com/2008/09/mst.pdf.

14 Surya P Subedi, supra note 7, p. 14.

15 Jorge Pérez Vera, La doctrina y cláusula Calvo en el derecho internacional, su evolución y práctica in Derecho Internacional de los Negocios (Bogotá: Universidad Externado de Colombia, 2003 ), p. 232.
} 
other standards, and that allow disputes to be solved not in local courts, but in international arbitration tribunals.

This trend was more evident during the nineties, when many Latin American Countries started to sign BITs. The model for such treaties was the one proposed by the capital exporting states even though many treaties were also signed between Latin America states. There are many reasons for the massive creation of these treaties in the region, but those can be summarized as follows: first, the continued failure of the establishment of an international multilateral framework in investment; second, the need for capital-exporting states to protect the investments of its nationals against the nationalizations that occurred years before as a result of the establishment of a new international economic order. ${ }^{16}$ Finally, there was a competition between Latin American states to attract foreign investors to its territories.

However, in the first years of the twenty-first century, a few arbitral awards that rule under BITs were perceived to affect Latin American interests. Specifically, there was an increasing concern that arbitral tribunals had gone too far "in limiting severing rights of the host countries." ${ }^{17}$ In addition, there was the concern that international arbitral tribunals affected the capacity of the host states to conduct their policy in delicate matters related with environmental and human rights issues. For that reason, many states of the region, especially Argentina, ${ }^{18}$ Ecuador, Venezuela and Bolivia, adopted strong positions that questioned the existence of the legal framework created in the nineties to protect investments and international transactions.

In this context, it can be said that the current trends in investment law are a new way of articulating the Calvo doctrine in the twenty-first century. This similarity emerges because the states that adopted a defensive approach towards investments rely on themselves in the key elements of the old Calvo doctrine: e.g. no greater rights to foreign investors; or, preventing international tribunals from deciding conflicts that arise from transactions involving investment.

In the region not all states have adopted this position, and some of them, like Chile, Peru, Colombia, and Costa Rica (among others), have been playing along with the current legal framework. Even more, they have adopted aggressive

\footnotetext{
${ }^{16}$ Liliana Lizarazo Rodriguez, "Acuerdos Bilaterales de Promoción y Protección a la Inversión (APPI)": 93; in: La Inversión Extranjera en Colombia Régimen Jurídico y Análisis Económico (Bogotá: Universidad Sergio Arboleda, 1997), p. 93.

${ }^{17}$ Surya P Subedi, supra note 7, p. 2.

18 Argentina suffered one of the deepest economical crises of the region that generated many international arbitral procedures, initiated by foreign investors who seek remedy for the losses experience after the measures, including expropriation, that Argentina's government take in an attempt to control the crisis. In many of those arbitral proceedings, Argentina alleged a "State of necessity". For more information about Argentina investor dispute after the economical crisis, we recommend: Kathleen Claussen, "The Casualty of Investor Protection in Times of Economic Crisis," The Yale Law Journal 2009.
} 
programs in order to achieve a greater number of BITs and FTAs agreements with capital-exporting states. In other words, these countries represent a position that leaves behind some elements of the Calvo doctrine, which means that they have internationalized the relationships with foreign investors.

These two trends of dealing with international transactions and foreign investments have also affected the dynamics inside the integrations structures in the region. In the next section, the trends expressed above will be analyzed under the scope of two of these integration efforts in the region, The Andean community (AC) and the Southern common Market (MERCOSUR).

\subsection{THE ANDEAN COMMUNITY (AC) AND ITS RELATION TO INTERNATIONAL TRANSACTION LAW}

Presently, the main issue that the $A C$ has to overcome to regulate international transactions and foreign investment is the absence of political consensus between its members. Even so, there have been several failed attempts to create a common foreign policy about these matters in order to negotiate with other countries as a united bloc. For example, in the past decade, there was an attempt by the AC to negotiate a FTA with the European Union (EU) as a bloc rather than each country on its own. After some struggles, Colombia and Peru decided to directly negotiate this agreement with EU, complaining about the apathy showed by Ecuador and Bolivia in the process. This experience demonstrates the lack of political consensus on the AC in this particular matter.

The following details provide important background information: the Andean Community (AC) is an integration process that started in 1969 with the signature of the Cartagena agreement by five countries: Bolivia, Colombia, Chile, Ecuador and Peru. Chile withdrew from it in 1976, but it has close relations with the remaining countries of the AC. Venezuela had been part of it since 1973, but also withdrew in 2006, leaving the AC with four active members. ${ }^{19}$ This process of integration not only focuses on commerce issues, but also includes important affairs, such as development, human rights and democracy. ${ }^{20}$ The $A C$ relies on a well-organized supranational structure, which includes a Tribunal of Justice that has helped to create a coherent legal framework.

Despite this structure, in recent years the AC has struggled trying to harmonize the trends on foreign investment. These different positions have influenced the norms about this matter. On December 21, 1970, Decision 24 of the

\footnotetext{
${ }^{19}$ For a detailed history of AC, visit webpage http://www.comunidadandina.org/ingles/quienes/brief.htm. 20 Elizabeth Salomon Garate, "Derecho Comunitario Andino": 55; in: Evolución Institucional de la Comunidad Andina: Perspectivas y Problemas (Lima: Pontificia Universidad Católica del Perú, 2003).
} 
CAN was enacted, which was sometimes misunderstood as the first international code of investment. However, this Decision should not be considered a code because it was really a common policy on investment. This Decision did not create standards of protection, but applied a logic of foreign investment control.

Some years later, in 1987, the AC issued Decision 220, replacing Decision 24, but this one had the same line of control as shown before. Finally, this Decision was replaced in 1991 by Decision 291, which introduced into AC law the so-called "Common Regime of Treatment of Foreign Capital and on Trademarks, Patents, Licenses and Royalties. ${ }^{\prime 21}$ This Decision moves away from the protectionism of its predecessors and goes forward with the globalization movement. Decision 291 introduces a set of guidelines and references by leaving more freedom and discretion to member states to regulate investment, which has been seen as a way to "effectively abandon any common policy on foreign investment."22

In the last years, there has been no development of any kind in this matter, and each member has adopted different strategies towards foreign investment. These strategies have split the Community in two groups: One formed by Colombia and Peru that seeks to increase the flow of investments by celebrating the more commercial and investment agreements as possible and the other one formed by Ecuador and Bolivia, which have both complained about the current framework. These latter two countries have also denounced instruments such as the International Center for Settlement of Investment Disputes, i.e. the ICSID convention. With this scenario, it seems very difficult that in the next years the AC would be able to have a strong, united policy regarding international transactions.

\subsection{SOUTHERN COMMON MARKET (MERCOSUR) AND INTERNATIONAL}

\section{TRANSACTION LAW}

This organization is the second integration process of the region; it started later than the $A C$, but has made some significant progress since its creation. MERCOSUR was established in 1991 by Brazil, Argentina, Uruguay and Paraguay, under the Treaty of Asunción, and later modified with Protocols of Brasilia and Ouro Preto. The last one has special importance because it established the institutional structure of the block. In 2005 parties signed the Protocol of adhesion of Venezuela, but this has not entered into force yet. The main issues of MERCOSUR are related with some constitutional provisions of its members that have been questioning the legal nature of this process and the rules created under it,

\footnotetext{
${ }^{21}$ The Spanish text of this decision can be found in:

http://intranet.comunidadandina.org/IDocumentos/c_Newdocs.asp?GruDoc $=07$.

${ }_{22}$ Peter Muchlinski, Multinational Enterprises \& The Law (Oxford University Press, 2007), p. 658.
} 
especially with the Constitutions of Brazil and Uruguay. ${ }^{23}$ There are also some doubts about the nature of the process as a trading bloc because of the unique features that were implemented. For that reason, MERCOSUR specialists labeled this process an "imperfect customs union," but undoubtedly this integration effort has created an acceptable increase of flows to the region. ${ }^{24}$

The MERCOSUR has two relevant agreements about investment: the Colonia Protocol of 1994 for the promotion and protection of investments flow inside of MERCOSUR (CP), and the Buenos Aires Protocol of 1994 that protects flows of investment from countries that are not part of MERCOSUR (from now on BAP). However, these protocols require that four states ratify them in order to enter into force, which has not occurred yet.

The BAP is an instrument that is meant to establish the basic conditions that each state member has to grant to investors outside MERCOSUR. ${ }^{25}$ However, this international instrument includes two features that make it equivalent to an open BIT: it includes the same standards that are usually used in a BIT, such as the fair and equitable standard, among others; ${ }^{26}$ but, it establishes a dispute resolution system that involves international arbitration upon decision of the investor. ${ }^{27}$ This feature is probably the most important of $\mathrm{BAP}^{28}$, but it is also the most controversial.

The dispute resolution between investors and states is one of the main reasons why the BAP has not been ratified yet, especially for countries like Brazil, which has refused to negotiate BITs for that particular reason. In the case of Brazil, arbitration was incorporated into its domestic law in 1996. However, it took some years until some constitutional issues and doubts were solved by local courts. ${ }^{29}$ Even though that arbitration was implemented in local practice, Brazil has not ratified any BIT despite the fact that many multinationals have a great presence on the continent. However, the second largest economy on the bloc is Argentina, who has accepted many arbitration clauses on its BITs, and has been the object of several legal actions by foreign investors on international tribunals. Therefore, these two divergent practices on managing international disputes related with

\footnotetext{
${ }^{23}$ Alejandro Perotti, "La suprnacionalidad en el constitucionalismo latinoamericano: el caso del Mercosur" in: Comunidad Andina de Naciones. Secretaría General; Integración y supranacionalidad: Soberanía y derecho comunitario en los países andinos (Lima: Secretaria General de la Comunidad Andina, 2001), p. 136.

${ }^{24}$ Guillermo Argerich, "Protocolos de inversiones extranjeras del MERCOSUR ¿Instrumentos útiles para el siglo XXI?": 211; in: Inversiones Extranjeras (Buenos Aires, 2005).

${ }^{25}$ As it is Stated in article 1 and 2 of BAP. The English version of BAP can be found in: http://www.sice.oas.org/Trade/MRCSRS/Decisions/dec1194e.asp

${ }^{26}$ It includes also, National Treatment, Most favored nation and Full protection and security.

27 Art. 2 H.2 of BAP.

${ }^{28}$ Guillermo Argerich, supra note 24: 219.

${ }^{29}$ Adriana Noemi Pucci, "Las nuevas Tendencias en materia de arbitraje comercial vigentes en el Brasil, ¿ofrecen suficiente protección a las inversiones extranjeras?": 221; in: Inversiones Extranjeras (Buenos Aires, 2005).
} 
investment make it difficult for MERCOSUR to develop a unified foreign policy on this matter.

In conclusion, the MERCOSUR framework for international transactions is wellstructured and includes a development on standards of treatment. However, the main weakness of this bloc is that the main instruments that deal with foreign investments, the BAP and the $\mathrm{CP}$, have strong resistance from its members, especially from Brazil. In that sense, it can also be concluded that MERCOSUR faces the same political consensus problems that is also evident in the Andean Community.

\section{INTERNATIONAL TRANSACTION LAW IN LATIN AMERICA IN THE} TWENTY-FIRST CENTURY

In order to understand the reaction of some countries towards investment, it is essential to state the importance that the concept of development has for the region, and how it was linked with the need of an increase of investment in order to achieve such development.

The concept of development became relevant for international law only after World War II, when many colonies around the globe started to gain independence, and, therefore, demanded the attention of Western states in order to reduce the poverty gap between them. Even though most Latin American states achieved independence in the nineteenth century, they adapted themselves into this developed-underdeveloped dynamic that replaced the colonizer-colonized one that existed in many territories before the $\mathrm{War}^{30}$. Since then, many institutions and structures created on the international level were made to achieve that purpose. Moreover, when the liberalized movement was strong in the early nineties, there was strong hope that these new institutions, such as the WTO or the programs of BITs proposed especially by the United States and some European nations, would allow Latin American states to leave behind problems related with underdevelopment.

However, the treaties that created the structure of the international economic order over the end of the past century did not include development as a main issue. What is more, the sole goal of those treaties was increasing the number of economic transactions around the world. That reality meant that development was only one reason to enter into those treaties and organizations, but it was not the objective. In that sense, the WTO's original goal was to increase commerce, while the object of any BIT or FTA is still to increase the flow of foreign direct investment.

30 Balakrishnan Rajagopal, International Law from Below (Cambridge: Cambridge University Press, 2003), p. 25. 
The twenty-first century brought to the region new perspectives about the way development should be achieved, and even though many countries still believe that the increase of international transactions is essential in changing the economical landscape, there are some that question the previously established legal framework. As previously stated, the way that these States structured this discontent was by retaking essential elements of the Calvo doctrine in order to criticize organizations like the WTO for commerce or the ICSID for the settlement of investment disputes.

In 2007 Bolivia took the lead by denouncing the ICSID convention, because it was said that this Centre for dispute resolution was in fact the tool for multinational corporations to control the governments of poor countries. Bolivia based this claim on the link that existed between the ICSID and the World Bank. This claim questions the independence of this Center (Quiroga, 447) because it has direct interests in some private investments that have been made through entities related to the World Bank.

Ecuador was another country in the region that denounced the ICSID Convention, but it went even further in 2008 by incorporating a prohibition for estate-investor arbitral proceedings in its new constitution. This new prohibition ${ }^{31}$ questioned the existence of all the BITs signed before by this State, but generated a variety of questions about its implementation. The main one was the status of the agreements and BITs signed by Ecuador before enacting its new constitution. Many scholars were worried about that by enacting a new constitution; Ecuador was actually trying to escape from obligations assumed, especially the ones that forced the country to defend itself in an ICSID arbitral tribunal.

There was a strongly held idea that this prohibition was only effective for the future, and does not affect the obligations already acquired, ${ }^{32}$ but in any case the issue was taken to the Ecuadorian Constitutional Court. The court concluded that the mechanism for settling disputes established on the BITs was unconstitutional, ${ }^{33}$ but it established that the way of proceeding was by denouncing such treaties, which indirectly recognized that the international obligation acquired were in force until the denouncing process would end in each treaty.

\footnotetext{
${ }^{31}$ This provision was incorporated in the article 422 that read as follow: "It shall not be possible to enter into international treaties or instruments in which the Ecuadorian State waives sovereign jurisdiction to international arbitration venues in contractual or commercial disputes between the state and private individuals or corporations".

32 Cesar Montaño, "Las relaciones internacionales y los tratados en la Consitución": 365; in: La Nueva Constitución del Ecuador (Quito: Universidad Andina Simón Bolivar, 2009).

${ }^{33}$ The Ecuadorian Constitutional court said: "The express prohibition to enter into agreements or treaties to which Ecuador cede sovereign jurisdiction at the behest of international arbitration and commercial contract disputes." The Court also sates: "the content of Article 8 and 9 of the Convention between Ecuador and the United Kingdom (...) submitted to Ecuador even ad-hoc arbitral tribunal for the resolution of disputes arising to an investor (...), which involves giving the state jurisdiction."
} 
After starting the denouncing process of its BITs, Ecuador proposed to the international community the idea of having Agreements of Commerce for Development, i.e. ACDs, that would incorporate protection for investment, but that would deal with important developing issues. Nonetheless, there have been very few countries interested in that type of treaty, and no ACD treaty has been signed yet. One of the reasons is that by accepting these special provisions, an exporting capital State would probably have to grant the same special conditions to other countries of the region.

As a conclusion, the positions of these States against the legal framework for transactions had a serious weakness, namely, that they do not offer or propose strong alternatives after leaving behind a mechanism of solving disputes like the ICSID. For that reason, many countries of the region did not follow this trend and, what is more, they are increasing the number of BITs or FTAs in order to increase commerce and attract international investments. For example, Chile is one of the countries that has been more active in the region, establishing an associate status with $A C$ and MERCOSUR blocs. In that same line, it has negotiated several bilateral treaties with many states like the United States and EU, recognizing the importance of creating a stable legal framework ${ }^{34}$ for transactions.

\section{TOWARDS A NEW UNDERSTANDING OF INTERNATIONAL INVESTMENT LAW}

The trends expressed in this article lead to a new conception of the regional role that international law should have in regulating transactions, especially in the area of foreign investment. This new understanding probably would not completely change the legal framework like some of the countries mentioned previously want, but would probably change the way that international investment is interpreted by tribunals.

Globalization has provoked a strange feature, which consists of traditional export countries who are receiving some investments from nationals of traditionally import countries. Therefore, some developed countries are not feeling comfortable when they have to face the investment protection ${ }^{35}$ in claims that use the strong standards that are contained in BITs. Even more, exporting states are adopting some of the arguments used by developing states to defend themselves against those claims, especially that no greater right should be granted to investors.

\footnotetext{
${ }^{34}$ María Isabel Castrillo and Bernardo Reyes, "Impactos del Tratado de Libre Comercio Chile - Union Europea: Una aproximacion al modelo de integracion económica": 125; in: Chile y MERCOSUR frente a la Unión Europea: Hacia la alianza estratégica o integración restringida? (Santiago: Alianza Chilena por un Comercio Justo y Responsable ACJR, 2004).

35 M. Sornarajah, supra note 6 , p. 337.
} 
That reality was seen when the NAFTA ${ }^{36}$ Free Trade Commission issued an interpretation note for the Chapter that regulated the standards of treatment of NAFTA treaty after a controversial first award in Pope \& Talbot v. Canada ${ }^{37}$, which extended the scope of responsibility of the host State. This award states that one of the standards of treatment, the fair and equitable standard established in Chapter 11 of NAFTA treaty, was a special standard that generates a broad scope of responsibility. For that reason, in its interpretation of that standard the NAFTA Commission established that this provision did not generate more obligations than the ones expected of any country on the international level and, therefore, it tried to content the rights that were granted in some arbitral tribunals, including Pope \&Talbot v. Canada.

These types of controversies about the scope of standards of treatment influence the future drafts of clauses that contain investment protection, such as the Fair and Equitable standard. For example, the Peru-USA FTA signed in 2006, actually incorporated a clause that clearly limits the fair and equitable standard of treatment ${ }^{38}$ with due process and denial of justice that are in any case related with the treatment expected for aliens in the international law, leaving no space for additional rights of investors.

The issue described above also contributes to the debate about the limits of international investment law. For many years, the way that scholars have looked at the international transactions related to investments has focused on the necessity of protecting investors in a possible hostile new legal environment. This way of reasoning came with the idea that when an economical actor decides to go to another country it will have to face a different legal and commercial environment, and therefore it will be exposed to possibly arbitrary decisions by the host country. Taking this into account, the law has focused only on protecting the investment and has failed to see the other part of the transaction, which is the interest of the state that hosts such investment.

For that reason, this new understanding of investment law in the region questions the current paradigm of the regulation of direct investment; it leaves the concept of a law for the protection of investment in order to create a concept of an integral international law of investment. Therefore, this new understanding is based on two main elements: first, that the law that regulates investment cannot be an independent one that ignores other international law areas, such as environmental law and human rights; and secondly, the law that regulates foreign investment has

\footnotetext{
${ }^{36}$ North America Free Trade Agreement, FTA signed between: Canada, México and USA in 1994.

37 Pope \& Talbot v. Canada, award 26 of June 2000, available on:

http://ita.law.uvic.ca/documents/DecisionSeptember27_Pope_001.pdf.

38 The same standard that generated the NAFTA FTA Commission interpretation note.
} 
to take into consideration that in an investment there are two parties: investor and a host country; so, when analyzing a case, a given tribunal has to consider also the behavior of the investor.

The first element implies that the law that regulates investment has to be considered a branch of international law. For many years this law had been seen as an independent one, with only one goal: the protection of investments. Nevertheless, this view ignores that the sources of international investment law are the same as for general international law. For that reason, the interpretation could be linked to other international public law branches. This approach seeks that tribunals that deal with investment disputes will take into account the principles established in the general international law.

One topic relevant to the region is the protection of the environment, because a great majority of the Latin American states had a great extension of sensible environmental territories, such as the ones in the Amazon jungle. For that reason, in their domestic legislation all these countries had incorporated special provisions for the protection of the environment, and in cases like in the Ecuadorian constitution, "mother nature" ${ }^{39}$ has been given the status of a subject of law. Therefore, there is a strong position in the region to link the standards of treatment of investors with the obligation of the state to protect its environment.

The Santa Elena vs. Costa Rica tribunal ${ }^{40}$ was one of the few tribunals to confront environmental issues while evaluating the right of a foreign investor to receive compensation for an expropriation that had taken place for environmental reasons. In this case, however, the respondent state did not prove that the investor was in fact contaminating the land located in a sensitive area. Taking this into account, the Tribunal concluded that, even though the expropriation was legitimate, it brings together the right of compensation. The Tribunal of Santa Elena also concluded that the social benefit that arose from the expropriation is not a matter that is related with the obligation to compensate and, for that reason, should not affect the valuation of such compensation. ${ }^{41}$

The second element implies that an international tribunal has to analyze the behavior of the investor while dealing with an investment claim. As previously stated, a transaction related with an investment involves two parties, so in order to consider the international responsibility of a state a Tribunal must consider the bad

\footnotetext{
${ }^{39}$ Expression used on Ecuadorian constitution.

${ }^{40}$ Compania del Desarrollo de Santa Elena, S.A. v. Republic of Costa Rica, Case No. ARB/96/1 (February $17,2000)$.

41 The Tribunal words: "While an expropriation or taking for environmental reasons may be classified as a taking for a public purpose, and thus may be legitimate, the fact that the Property was taken for this reason does not affect either the nature or the measure of the compensation to be paid for the taking. That is, the purpose of protecting the environment for which the Property was taken does not alter the legal character of the taking for which adequate compensation must be paid .... The international source of the obligation to protect the environment makes no difference."
} 
faith that an investor can have in a particular case. However, the conduct of the investor has not been considered in most of the investment claims, and only a few tribunals have analyzed the investors conduct while interpreting treaties.

One of these approaches was taken in Azinian v. Mexico, ${ }^{42}$ a NAFTA based tribunal that deals with an investment in Mexico that was terminated by local authorities after finding several irregularities. The Tribunal denied the claim of the investors because it found that it did not breach international obligations, but it also analyzed the performance and the credibility of the claimants during the arbitral proceeding. ${ }^{43}$ Therefore, this case brings to the debate the importance that the misconduct of an investor may have while evaluating an investment claim, which has lead to many factors in the sense that "there is no international responsibility if the investor has conducted himself in bad faith." ${ }^{44}$

This case brings to the debate the existence of a right of a State to terminate an investment that has been conducted improperly, contaminating the environment, affecting human rights or that simply has not fulfilled the minimum standards of corporate accountability. If the negligent behavior of an investor is not taken in consideration while dealing with claims, there is the probability that the state that has put an end to it will be liable under international law.

\section{CONCLUSIONS}

In the first part of this article, it was stated that globalization generated a intersection of different legal trends. This intersection is evident in Latin America because states have to choose between staying within the international legal framework established in the nineties, or trying to go back to the fundamental points of the Calvo doctrine.

The first trend in the region is the one that has a defensive approach towards investment and it is headed especially by Venezuela, Bolivia and Ecuador. These countries, in a way, are trying to re-appropriate the fundamentals of Calvo doctrine that seek to nationalize the transactions with foreign investors. For that purpose, in recent years some of these countries withdrew from the ICSID convention because it was alleged to have a "lack of balancing between public and private interests." ${ }^{45}$ In the case of Ecuador it is more evident because this country not only withdrew

\footnotetext{
${ }^{42}$ Azinian, Kenneth Davitian y Ellen Baca v. The United States of America (Azinian v. México).

43 The Tribunal stated the following: "121. By way of a final observation, it must be said that the Claimants' credibility suffered as a result of a number of incidents that were revealed in the course of these arbitral proceedings, and which, although neither the Ayuntamiento nor the Mexican courts would have been aware of them before this arbitration commenced, reinforce the conclusion that the Ayuntamiento was led to sign the Concession Contract on false pretences."

44 Gabriel Calvazos, The Fair and Equitable Treatment Standard (Saarbrucken: VDM Verlag, 2008), p. 98.

45 Surya P. Subedi, supra note 7, p. 3.
} 
from the ICSID, but also, upon the enactment of a new Constitution in 2008, it incorporated a prohibition to any state-investor arbitral proceeding outside the region.

By contrast, there are countries such as, among others, Colombia, Peru, Costa Rica, and Chile, that have played along with the globalization process and have sought to achieve a great number of FTAs and BITs, not only with export capital states, but also with developing nations as well. These countries have incorporated in their domestic legislation some of the principles extracted from the international law of foreign investments. For example, Peru has incorporated a stability of ten years on its tax regulation, going further on one of the elements of the fair and equitable treatment standard that stated the need for having a predictable legal framework and respecting legitimate expectations of the investor. ${ }^{46}$

In any case, it is evident that a large country could become an engine for the integration process. Brazil, which is the country that has the economic size to start this process, traditionally has had no intention of leading such an enterprise, or this has not proved to be necessary for expanding its economy. In addition, as stated before, Brazil has refused to sign BITs even with countries of the region, and just a few years ago incorporated arbitration on its domestic legislation.

Based upon what has been already discussed, the making of a single foreign policy of the region about these matters does not appear to be likely in the near future, especially taking into account that a single foreign policy has not been reached in the $A C$ or in MERCOSUR. However, what seems possible is a common understanding of the way that international investment law should be interpreted by tribunals, especially while dealing with matters related with environmental damage, human rights and the bad faith of the investors. This will contribute to rebuilding the trust of those states that have faded away from the current legal framework, and it will be a incentive for them to eventually rejoin the system instead of trying to build one on their own, which seems like a difficult task.

In addition, the lessons that can be learned from this region are that there are two key elements needed in a globalization legal process for developing countries: flexibility, in the sense of interaction with as many international actors as possible, and the development of strong domestic institutions, because, as Schill said, "the systems of many developing and transitioning economies do not provide the institutions that are necessary to attract and sustain foreign investment and to integrate developing economies into a global market." ${ }^{47}$

\footnotetext{
${ }^{46}$ Jeswald W. Salacuse, The Law of Investment Treaties (Oxford University Press, 2010), p. 233.

47 Stephan W. Schill, The Multilateralization of International Investment Law (Cambridge: Cambridge University Press, 2009), p. 5.
} 
The best example in the region of a country that has developed these key elements is Chile, because Chile has successfully negotiated FTAs with the European Union, and the United States among many other export-capital states. In addition, this country has excellent relationships with its neighbors and even though it is not an active member of AC and MERCOSUR, it has an associate status with these two regional blocs. However, Chile has built institutions that have also played a key role in attracting capital flows to its territory.

The states of the region will have to make an additional effort to achieve basic consensus, which will allow them to reach equilibrium in the crossroad described in this article. Finally, there is also the task for this region to build institutions on the regional and national level solid enough to endure the current legal globalization process.

\section{BIBLIOGRAPHY}

1. Argerich, Guillermo. "Protocolos de inversiones extranjeras del MERCOSUR $i$ Instrumentos útiles para el siglo XXI?": 208-219. In: Inversiones Extranjeras. Buenos Aires, 2005.

2. Blackaby, Nigel. "El arbitraje según los tratados de inversión y los capítulos de inversión en los tratados de libre comercio": 285-308. In: El Contrato de Arbitraje. Bogotá: Legis Editores, 2005.

3. Calvazos, Gabriel. The Fair and Equitable Treatment Standard. Saarbrucken: VDM Verlag, 2008.

4. Carbonell, M. Globalización y Derecho: Algunas Coordenadas para el Debate. Quito: Ministerio de Justicia Ecuador, 2009.

5. Castrillo, María Isabel, and Bernardo Reyes. "Impactos del Tratado de Libre Comercio Chile - Union Europea: Una aproximacion al modelo de integracion economica": 99-135. In: Chile y MERCOSUR frente a la Unión Europea: Hacia la alianza estratégica o integración restringida? Santiago: Alianza Chilena por un Comercio Justo y Responsable ACJR, 2004.

6. Dolzer, Rudolf, and Chrisoph Schreurer. Principles of International Investment Law. Oxford University Press, 2008.

7. Friedman, L. M. "One World: Notes on the Emerging Legal Order": 23-39. In: Transnational Legal Processes. Butterworths LexisNexis, 2002.

8. Lizarazo Rodriguez, Liliana. "Acuerdos Bilaterales de Promoción y Protección a la Inversión (APPI)": 93-150. In: La Inversión Extranjera en Colombia Régimen Jurídico y Amálisis Económico. Bogotá: Universidad Sergio Arboleda, 1997. 
9. Montaño, Cesar. "Las relaciones internacionales y los tratados en la Consitución ecuatoriana de 2008": 353-382 In: La Nueva Constitución del Ecuador. Quito: Universidad Andina Simón Bolivar, 2009.

10. Muchlinski, Peter T. Multinational Enterprises \& The Law. Oxford Unversity Press, 2007.

11. Orrego Vicuña, Francisco. De los Contratos y Tratados en el Mercado Mundial en Inversiones Extranjeras. Buenos Aires, 2005.

12. Pérez Vera, Jorge. La doctrina y cláusula Calvo en el derecho internacional, su evolución y práctica in Derecho Internacional de los Negocios. Bogotá: Universidad Externado de Colombia, 2003.

13. Perotti, Alejandro. "La suprnacionalidad en el constitucionalismo latinoamericano: el caso del Mercosur": 136-144. In: Comunidad Andina de Naciones. Secretaría General; Integración y supranacionalidad: Soberanía y derecho comunitario en los países andinos, La supranacionalidad en el constitucionalismo latinoamericano. Lima: Secretaria General de la Comunidad Andina, 2001.

14. Pucci, Adriana Noemi. "Las nuevas Tendencias en materia de arbitraje comercial vigentes en el Brasil, ¿ofrecen suficiente protección a las inversiones extranjeras?": 220-239, In: Inversiones Extranjeras. Buenos Aires, 2005.

15. Rajagopal, Balakrishnan. International Law from Below. Cambridge: Cambridge University Press, 2003.

16. Reyes, Oscar Efrén. Breve Historia del Ecuador. Quito: Graficos Nacionales, 1949.

17. Salacuse, Jeswald W. The Law of Investment Treaties. Oxford University Press, 2010.

18. Salomon Garate, Elizabeth. "Evolución Institucional de la Comunidad Andina: Perspectivas y Problemas": 21-56 In: Derecho Comunitario Andino. Lima: Pontificia Universidad Católica del Perú, 2003.

19. Sánchez Mussi, Adriana. "International Minimum Standard of Treatment." Wordpress Web Site, 2008 // http://asadip.files.wordpress.com/2008/09/mst.pdf.

20. Schill, Stephan W. The Multilateralization of International Investment Law. Cambridge: Cambridge University Press, 2009.

21. Sornarajah, M. The International Law on Foreign Investment. Cambridge: Cambridge University Press, 2004.

22. Subedi, Surya P. International Investment Law Reconciling Policy and Principle. Portland: Hart Publishing, 2008. 